\title{
Pemanfaatan Teknologi untuk Mendukung Kegiatan Belajar Secara Mandiri (Studi Kasus Penggunaan Podcast oleh Mahasiswa di Kota Palangkaraya)
}

\author{
Norhayati ${ }^{1)}$, Sherly Jayanti ${ }^{2)}$ \\ Sistem Informasi ${ }^{1)}$, Manajemen Informatika ${ }^{2)}$ \\ Sekolah Tinggi Manajemen Informatika dan Komputer (STMIK) Palangkaraya \\ Jalan G. Obos, No. 114, Palangkaraya, Kalimantan Tengah \\ Email: inoynorhayati@gmail.com ${ }^{1)}$,sherlyjayanti85@gmail.com²)
}

\begin{abstract}
Abstrak
Penelitian ini bertujuan untuk mengetahui sejauh mana pemanfaatan teknologi oleh para mahasiswa di kota Palangkaraya. Teknologi yang menjadi fokus disini adalah podcast. Podcast merupakan audio dan video yang marak digunakan sebagai sarana penyampaian informasi. Informasi yang diberikan sangat beragam, hal ini tergantung dari narasumber atau pembicara dalam topik podcast tersebut. Metode yang digunakan dalam penelitian ini adalah metode deskriptif studi. Data-data dikumpulkan dengan menggunakan lembar kuisioner semi terbuka and wawancara semi terstruktur. Analisa data yang dilakukan oleh peneliti adalah analisis persentase. Sehingga kemudian hasil analisis tersebut dijabarkan secara jelas guna menggambarkan keadaan objek secara konkrit dan riil. Hasil dari penelitian ini menyatakan bahwa 97\% mahasiswa di kota Palangkaraya telah mengenal dan menggunakan podcast sebagai sarana untuk mendapatkan informasi terkait dengan bidang ilmunya masing-masing. Akan tetapi beberapa dari mereka masih mengalami kendala dalam memahami podast yang berbahasa Inggris.
\end{abstract}

Keywords: podcast, pemanfaatan teknologi, belajar mandiri, mahasiswa kota Palangkaraya

Abstract

This study aims to determine the extent of the use of technology by students in Palangkaraya city. The technology that is the focus here is podcasts. Podcasts are audio and video that are widely used as a means of delivering information. The information provided is very diverse; this depends on the resource person or speaker on the topic of the podcast. The method used in this research is descriptive study method. Data were collected by using semi-open questionnaire sheets and semi-structured interviews. Data analysis conducted by the researcher is a percentage analysis. So then the results of the analysis are spelled out clearly in order to describe the state of the object in a concrete and real way. The results of this study stated that $97 \%$ of students in Palangkaraya city had known and used podcasts as a means to obtain information related to their respective fields of study. However, some of them still experience difficulties in understanding Englishlanguage podcasts.

Keywords: podcast, technology utilization, independent learning, Palangkaraya city students

\section{PENDAHULUAN}

Pesatnya perkembangan teknologi dalam dunia pendidikan telah mempengaruhi gaya belajar siswa pada masa kini. Kemudahan dalam mengakses informasi melalui media internet juga telah dimanfaatkan oleh banyak orang untuk mendapat materi bejalar yang sesuai dengan keinginan masingmasing. Kecendrungan perubahan dan inovasi dalam dunia pendidikan akan terus terjadi dan berkembang dalam memasuki abad ke- 21 sekarang ini. Perubahan tersebut antara lain: lebih mudah dalam mencari sumber belajar, lebih banyak pilihan untuk menggunakan dan memanfaatkan ICT, makin meningkatnya peran media dan multi media dalam kegiatan pembelajaran (Budiman, 2017).Kemunculan podcast, yang merupakan salah satu produk teknologi, telah memberikan pengaruh kepada gaya belajar anak muda pada sama kini. Podcast sendiri merupakan suatu teknologi baru yang digunakan untuk penyiaran program audio di internet. Podcasting pada mulanya digunakan untuk 
menyampaikan informasi dan hiburan. Akan tetapi, para pendidik melihat potensi yang besar dari penggunaan podcast yang dapat digunakan dalam proses belajar dan mengajar, sebagai contoh, ada banyak kemungkinan penggunaan dari podcast yang dapat di fungsikan secara maksimal. Hal ini bergantung pada kreatifitas dan imajinasi.

Ada beberapa hal yang dapat dimanfaatkan dalam penggunaan podcast untuk belajar bahasa Inggris, diantaranya adalah sebagai metode yang efektif untuk melatih kemampuan listening comprehension/menyimak dan untuk memperbaiki pengucapan (pronunciation) dalam berbicara. Beberapa keuntungan dari penggunaan Podcast ini adalah sebagai berikut; (1) Pengucapan (Pronunciation) mahasiswa dalam bahasa Inggris mengalamai perbaikan yang signifikan. Beberapa kosa kata dalam bahasa Inggris yang sebelumnya selalu salah diucapkan, setelah post test II, hal tersebut hampir tidak terjadi lagi, (2) Mahasiswa yang sebelumnya belum terbiasa dengan diskusi sekarang menjadi lebih terbiasa dalam mengemukakan ide atau opininya di depan orang lain, (3) Mahasiswa juga terlihat lebih pecaya diri saat harus berbicara bahasa Inggris karena mereka telah bisa menggunakan pengucapan yang benar, (4) Pemanfaatan podcast juga memperbaiki kemampuan listening mahasiswa, karena seringnya mendengarkan podcast, kemampuan listening mahasiswa juga menjadi lebih baik. (Riyani \& Sari, 2020).

Para guru disekolah formal pun telah memanfaatkan podcast untuk memaksimalkan proses dan hasil belajar listening comprehension diruang kelas. Hal ini seperti dikemukakan oleh Abdulrahman, T., Basalama, N., \& Widodo, M. R. (2018) yang dalam penelitiannya menyatakan bahwa para siswa atau pembelajar memiliki tanggapan yang positif terhadap penggunaan podcast pada saat listening comprehension dalam pelajaran bahasa Inggris, siswa merasakan bahwa dengan menggunakan podcast, maka materi listening comprehension menjadi lebih otentik, dengan mendengarkan podcast untuk skill listening comprehention maka membuat kegiatan belajar mengajar menjadi lebih menyenangkan. Hal ini membuat mereka lebih termotivasi untuk belajar bahasa Inggris.

Pada level siswa yang lebih tinggi, misalnya siswa pada sekolah tinggi atau perguruan tinggi, mereka yang telah memahami teknologi, dapat dekat mudah mengakses podcast secara mandiri. Selain itu, mudahnya pemakaian podcast menyebabkan podcast dapat diputar kapan saja dan dimana saja bahkan dengan menggunakan perangkat pemutar sederhana, misalnya komputer atau telepon pintar. Para siswa ini memiliki kebebasan dalam menggunakan perangkat teknologi yang dimilikinya, sehingga jika mereka dapat memanfaatkannya dengan baik maka hal itu dapat membantu mereka untuk meningkatkan kemampuan bahasa Inggrisnya secara mandiri. Berkaitan dengan situasi dan kondisi yang telah dijabarkan tersebut, maka penulis tertarik untuk melakukan penelitian mengenai bagaimanakah pemanfaatan teknologi untuk mendukung kegiatan belajar secara mandiri (studi kasus: penggunaan podcast dikalangan mahasiswa kota Palangkaraya)".

Berdasarkan penjabaran tersebut diatas, maka penulis merumuskan masalah sebagai berikut; bagaimana pemanfaatan teknologi untuk mendukung kegiatan belajar secara mandiri (studi kasus: penggunaan podcast dikalangan mahasiswa kota Palangkaraya).

Mengingat adanya berbagai keterbatasan selama penelitian berlangsung dan arah penelitian dapat lebih terfokus, diberikan batasan-batasan permasalahan pada penelitian yang meliputi; penelitian dilaksanakan di kota Palangkaraya, objek dari penelitian ini adalah mahasiswa yang terdapat pada kota Palangkaraya, topik utama dari pembahasan penelitian ini adalah pemanfaatan teknologi, berupa podcast, untuk mendukung kegiatan belajar secara mandiri serta hasil dari penelitian ini hanya menggambarkan bagaimana pemanfaatan teknologi untuk mendukung kegiatan belajar secara mandiri (studi kasus penggunaan podcast dikalangan mahasiswa kota Palangkaraya). 
Penelitian ini bertujuan untuk; mengidentifikasi, menjelaskan dan menganalisis pemanfaatan teknologi untuk mendukung kegiatan belajar secara mandiri (studi kasus: penggunaan podcast dikalangan mahasiswa kota Palangkaraya).

Manfaat penelitian ini ada dua, yakni secara teoritis dan secara praktis. Secara teoritis, manfaat penelitian ini adalah memberikan kontribusi terhadap bidang teknologi, dalam pemanfaatan media Podcast untuk mendukung kegiatan belajar secara mandiri. Sementara itu, secara praktis, hasil penelitian ini diharapkan dapat berguna bagi para mahasiswa agar dapat menyikapi secara bijak pemanfaatan Podcast sehingga mereka dapat memaksimalkan manfaat teknologi tersebut dengan baik.

\section{TINJAUAN PUSTAKA}

1. Definisi podcast

Podcast acapkali didefinisikan dengan dengan materi yang memiliki format audio. Dalam kamus Oxford, podcast dinyatakan sebagai "a digital audio file made available on the Internet for downloading to a computer or portable media player, typically available as series, new instalments of which can be received by subscribers automatically."

Seiring dengan majunya perkembangan teknologi, podcast juga mengacu pada materi yang berbentuk video. Sehingga, secara bentuk format, dapat disimpulkan bahwa podcast dapat mengacu pada materi yang berbentuk audio maupun video. Sementara itu, pihak perusahaan Apple memiliki batasan tersendiri terkait podcast, yakni siaran audio dan video yang tersedia di internet untuk diputarkan pada perangkat portable atau komputer, seperti iPad, Ipod, atau Mac.

Berdasarkan hal tersebut, maka podcast dapat diartikan sebagai materi, baik itu audio ataupun video yang tersedia di internet yang dapat secara otomatis dipindahkan ke komputer atau media pemutar portable baik secara gratis maupun berlangganan. (Fadilah Efi, dkk:2017)

\section{Penggunaan Podcast di Indonesia}

Menurut hasil penelitian Fadilah Efi, dkk: (2017), Potensi podcast terletak pada keunggulannya; dapat diakses secara otomatis, mudah dan kontrol ada di tangan konsumen, dapat dibawa-bawa, dan selalu tersedia. Formula kesuksesan konten podcast audio diantaranya terletak pada pengemasan yang ringan dan menarik dengan tawaran 'nilai' yang jelas bagi calon pengakses.

Dalam pemutaran audio atau video podcast, tidaklah diwajibkan untuk memiliki smartphone, iPod atau tablet khusus. Para pengguna dapat mengunduh file audio atau video podcast, lalu disimpan kedalam memori komputer atau perangkat penyimpanan sehingga dapat didengarkan kemudian hari secara offline/luring.

Berkenaan dengan hal tersebut, maka podcast, baik itu yang memiliki format audio maupun video, dapat diakses dengan mudah oleh berbagai kalangan, terutama mahasiswa. Selain itu, podcast juga dapat diputar pada berbagai berangkat, baik itu telepon genggam, komputer dan alat pemutar audio dan video lainnya.

3. Jenis-jenis podcast

Adapun jenis-jenis podcast yang sering digunakan adalah; basic podcast hanya audio saja, enhanced podcast (audio dengan tambahan slide dan gambar) dan vodcast (audio dan video).

Basic podcast dibuat dengan menggunakan alat perekanm suara atau audacity. Jenis formatnya adalah .mp3. Enhanced podcast ditampilkan dengan narasi dan banyak bagian. Jenis formatnya adalah .mp4a, .,p4b, tapi bisa juga dalam bentuk .mov filed dan bahkan .pdf. Vodcast dibuat dengan menggunakan kamera perekam digital dan aplikasi video editing seperi iMovie. Jenis formatnya adalah .mp4 atau .mov. 
4. Penggunaan podcast didunia Pendidikan

Berdasarkan hasil penelitian Panday P Prachi, 2009, penggunaan podcast pada sekolah atau universitas serta proses pembuatan dan pemanfaatan podcast secara berkesinambungan dapat digunakan untuk berbagai macam disiplin ilmu. Dalam penerapan riilnya, penggunaan podcast dapat merupakan sebagai bagian dari tugas. Misalnya, mahasiswa dari jurusan teknologi pendidikan atau ilmu pendidikan dapat terlibat dalam proses penciptaan ide (menghasilkan dengan ide pedagogis yang tepat); sementara itu para mahasiswa dari jurusan jurnalisme/komunikasi bisa membuat naskah podcast; siswa dari jurusan multimesia dapat merekam/mengedit podcast; para siswa jurusan musik dapat membuat sampel musik yang dapat digunakan untuk meningkatkan kualitas podcast; para mahasiswa dari jurusan teknologi infromasi dapat menjaga kebersinambungan podcast.

Berdasarkan uraian tersebut maka dapat disimpulkan bahwa ada banyak hal yang dilakukan terkait dengan podcast, baik itu dalam proses pembuatannya atau pun dalam pemanfaatannya.

Audio memainkan peran yang sangat penting dalam proses pembelajaran. Audio memiliki beberapa karakteristik yang kurang dimiliki teks. Audio dapat memiliki dampak signifikan pada pemahaman beberapa informasi. Seringkali, kita mengerti lebih baik dalam kuliah tatap muka daripada ketika kita membaca konten yang sama kita sendiri. Menurut Clark dan Walsh, "mendengarkan bersifat instingtual, [sedangkan] membaca dan menulis tidak "(seperti dikutip dalam Chan dan Lee, 2005, hal. 62). Frekuensi modulasi suara manusia memiliki keunggulan dibandingkan teks ketika menyampaikan informasi apa pun. Audio memiliki fungsi yang sangat kuat untuk menyampaikan informasi. Namun, audio memang memiliki beberapa kekurangan didalamnya. Misalnya, terlalu banyak informasi dalam format audio mungkin cenderung dapat mengalihkan perhatian pendengar.

Menurut pendapat Dewan Skotlandia untuk Pendidikan Teknologi, audio adalah media sangat luar biasa kuat untuk menyampaikan perasaan, sikap dan suasana belajar dan kurang kuat untuk menyampaikan detail dan fakta. Dari rekaman audio 30 menit, orang akan ingat opini dan argumen umum dan tidak terlalu banyak fakta dan angka (sebagaimana dikutip dalam Chan dan Lee, 2005).

Podcasting memliki kelebihan seperti yang dimiliki audio. Durbridge mengidentifikasi keunggulan audio pendidikan sebagai kemampuannya untuk mempengaruhi faktor kognitif melalui kejelasan instruksi dan aspek emosional pembelajaran dengan menyampaikan kedekatan dan hubungan dengan pengajar (sebagaimana dikutip dalam Edirisingha, 2006).

Hargis dan Wilson (2008) berhubungan konsep podcasting untuk pemrosesan informasi dan pembelajaran konseptual. Bagi para pendidik, hal ini bisa menjadi nilai lebih, antara lain, yakni sebagai berikut; a) siswa sudah terbiasa menggunakan pemutar mp3. b) pendidik dapat meminta mereka untuk menggunakannya untuk tujuan pendidikan. Menurut Clark dan Walsh, mendengarkan pemutar mp3 di depan umum "dapat diterima secara sosial". c) pelajar muda modern saat ini (yang mungkin tidak sabar dengan bentuk pengajaran dan pembelajaran tradisional) lebih menyukai perangkat ini yang memiliki daya tarik tersendiri (dikutip dalam Chan dan Lee, 2005).

\section{METODE PENELITIAN}

Metode yang digunakan dalam penelitian ini adalah metode deskritif studi. Dimana peneliti mengumpulkan data dilapangan, kemudian menganalisa data tersebut, hingga dapat ditarik kesimpulan yang dapat menggambarkan keadaaan yang pada objek penelitian. Dalam penelitian ini, peneliti mengambil situasi sosial dari mahasiswa perguruan tinggi yang ada di kota Palangkaraya. 
Data diperoleh dengan menggunakan kuesioner dengan jenis pertanyaan semi terbuka dan wawancara semi terstruktur. Analisa data yang digunakan adalah dengan menghitung persentase jawaban untuk kemudian dijabarkan untuk menjawab poin-poin pertanyaan dalam kuesioner.

\section{HASIL DAN PEMBAHASAN}

Data yang diperoleh diambil dari 67 (enam puluh tujuh) orang mahasiswa yang secara acak dipilih dari lima perguruan tinggi yang terdapat dikota Palangkaraya yang memiliki latar belakang pendidikan berbasis teknologi atau memiliki pengetahuan tentang menggunaan teknologi. Pendapat tenaga pendidik atau pengajar juga diperlukan untuk memberikan deskripsi yang jelas tentang penggunaan podcast seingga dapat dijelaskan secara deskriptif.

Kelompok pertanyaan pada bagian A berisikan tentang program studi, umur dan jenis kelamin responden/mahasiswa. Kelompok pertanyaan pada bagian B bertujuan untuk mengetahui seberapa banyak interaksi responden/mahasiswa dengan penggunaan podcast. Kelompok pernyataan pada bagian $\mathrm{C}$ bertujuan untuk mengetahui persepsi responden/mahasiswa terhadap pemanfaatan penggunaan podcast. Kelompok pernyataan pada bagian D bertujuan untuk mengetahui persepsi responden/mahasiswa terhadap belajar bahasa Inggris. Kelompok pertanyaan pada bagian E bertujuan untuk mengetahui kesulitan dan opini responden/mahasiswa terkait penggunaan podcast untuk belajar bahasa Inggris.

Adapun hasil analisa dari peneltian ini adalah sebagai berikut: Berdasarkan hasil dari kuisioner yang telah dibagikan, dapat diketahui fakta bahwa;

1. Hasil analisa mengenai interaksi responden/mahasiswa dengan penggunaan podcast.

Sebanyak 97\% mahasiswa memahami atau telah mengetahui apa yang dimaksud dengan podcast. Sebanyak 20\% mahasiswa mendengarkan podcast sebanyak 7 sampai dengan 9 kali dalam sebulan. Sebanyak $71 \%$ mahasiswa mendengarkan podcast dari berbagai sumber selain dari British Council, yakni BBC Podcast, Absolutely Intercultureal, VOA dan sumber lainnya). Sebanyak 49\% mahasiswa mendengarkan podcast melalui komputer/laptop, 52\% mahasiswa mendengarkan podcast melalui pemutar MP3, 67\% mahasiswa menggunakan telepon genggam, $2 \%$ mahasiswa mendengarkan podcast menggunakan komputer tablet PC dan 7\% mahasiswa menggunakan komputer tab/tablet. Sebanyak 56\% mahasiswa mendengarkan podcast di rumah atau kost, 71\% mahasiswa mendengarkan podcast dikampus, $8 \%$ mahasiswa mendengarkan podcast dijalan dan 34\% mahasiswa mendengarkan podcast ditempat lainnya. Sebanyak 53\% mahasiswa mendengarkan podcast dengan sambil melihat transkripnya, sedangkan $46 \%$ mahasiswa mendengarkan podcast dengan tidak sambil melihat transkripnya.

2. Hasil analisa mengenai persepsi responden/mahasiswa terhadap pemanfaatan penggunaan podcast.

Sebannyak 53\% mahasiswa setuju bahwa dokumen suara podcast dapat diperoleh dengan mudah. Sebanyak $64 \%$ mahassiwa setuju bahwa dokumen suara podcast dapat diputar/dimainkan dengan mudah. Sebanyak 52\% mahasiswa menyatakan ragu-ragu bahwa dengan mendaftar pada situs yang menyediakan layanan podcast dapat memudahkan mereka untuk memperoleh dokumen podcast. Sebanyak $40 \%$ mahasiswa menyatakan kurang setuju bahwa mereka tidak mengetahui bagaimana menggunakan atau memanfaatkan podcast. Sebanyak $47 \%$ mahasiswa menyatakan setuju bahwa durasi yang ideal untuk mendengarkan podcast adalah 8 sampai dengan 10 menit. Sebanyak $61 \%$ mahasiswa menyatakan setuju bahwa dengan adanya transkrip percakapan maka memudahkan mereka dalam memahami audio podcast dengan lebih baik. sebanyak 41\% mahasiswa menyatakan setuju bahwa mereka menikmati mendengarkan podcast. Sebanyak $44 \%$ mahasiswa menyatakan setuju bahwa dengan mendengarkan dokumen podcast dalam bahasa 
inggris telah membuat mereka lebih termotivasi untuk belajar bahasa inggris. Sebanyak $50 \%$ mahasiswa menyatakan setuju bahwa mereka merasa podcast adalah hal yang menarik. Sebanyak $50 \%$ mahasiswa menyatakan setuju bahwa mereka akan mendengarkan podcast dimana yang akan datang. Sebanyak 50\% mahasiswa menyatakan setuju bahwa podcast bermanfaat untuk belajar bahasa Inggris. Sebanyak 44\% mahasiswa menyatakan setuju bahwa mendengarkan podcast adalah cara yang efektif untuk meningkatkan kemampuan mendengarkan dalam bahasa inggris. Sebanyak 55\% mahasiswa menyatakan tidak setuju bahwa podcast bukanlah hal yang menyenangkan bagi mereka. Sebanyak 52\% mahasiswa menyatakan setuju bahwa mendengarkan podcast adalah hal yang efektif bagi saya untuk meningkatkan kemampuan saya dalam memahami percakapan. Sebanyak 50\% mahasiswa menyatakan tidak setuju bahwa mendengarkan podcast adalah hal yang sia-sia bagi mereka. Sebanyak 55\% mahasiswa menyatakan setuju bahwa setelah mendengarkan podcast berbahasa Inggris, mereka menjadi lebih bisa menerima untuk belajar bahasa melalui podcast dimasa yang akan datang. Sebanyak $47 \%$ mahasiswa menyatakan setuju bahwa mereka akan merekomendasikan penggunaan podcast bagi orang lain yang sesdang belajar bahasa Inggris.

3. Hasil analisa mengenai persepsi mengetahui persepsi responden/mahasiswa terhadap belajar bahasa Inggris.

Sebanyak 46\% mahasiswa menyatakan sangat setuju bahwa belajar bahasa Inggris adalah hal yang menyenangkan. Sebanyak $44 \%$ mahasiswa menyatakan sangat setuju bahwa mereka sangat ingin belajar bahasa Inggris. Sebanyak 43\% mahasiswa menyatakan sangat tidak setuju bahwa mereka tidak suka bahasa Inggris. Sebanyak 35\% mahasiswa menyatakan setuju bahwa mereka belajar bahasa Inggris karena bahasa Inggris adalah mata kuliah umum yang wajib diambil. Sebanyak 58\% mahasiswa menyatakan sangat setuju bahwa berbicara dalam bahasa Inggris dengan lancar dapat memberikan kesan yang baik. Sebanyak 58\% mahasiswa sangat setuju menyatakan bahwa belajar bahasa Inggris adalah hal yang penting untuk masa depan mereka. Sebanyak 49\% mahasiswa menyatakan setuju bahwa belajar bahasa Inggris dapat membantu mereka untuk mendapatkan pekerjaan yang lebih baik dimasa yang akan datang. Sebanyak 46\% mahasiswa menyatakan setuju bahwa belajar bahasa Inggris adalah hal yang penting bagi mahasiswa pada jenjang diploma dan sarjana. Sebanyak 53\% mahasiswa menyatakan setuju bahwa mereka memerlukan bahasa Inggris ketika mereka melakukan perjalanan keluar negeri. Sebanyak 52\% mahasiswa menyatakan sangat setuju bahwa mereka memerlukan bahasa Inggris ketika mereka menggunakan atau mencari informasi di internet. Sebanyak 55\% mahasiswa menyatakan tidak setuju bahwa mereka tidak memiliki waktu untuk meningkatkan kemampuan bahasa Inggris. Sebanyak $64 \%$ mahasiswa menyatakan setuju bahwa mereka senang mendengarkan lagu dalam bahasa Inggris. Sebanyak 49\% mahasiswa menyatakan setuju bahwa mereka senang menonton film yang menggunakan bahsa Inggris. Sebanyak 55\% mahasiswa menyatakan setuju bahwa mereka senang belajar bahasa Inggris.

Berdasarkan hasil analisa dari data tersebut diatas, maka dapat dibuat kesimpulan sebagai berikut.

1. Sebagian besar mahasiswa di kota Palangkaraya, sebanyak 97\%, telah terbiasa menggunakan podcast untuk belajar bahasa Inggris. Hal ini dikarenakan pada saat belajar bahasa Inggris dikelas, pengajar telah menggunakan podcast sebagai salah satu media ajar. Selain mendengarkan podcast diruang kelas, mahasiswa juga dapat secara bebas mendengarkan podcast ditempat lain secara santai. Sebab itu, podcast menjadi salah satu media yang acapkali mereka gunakan pada saat mereka belajar bahasa Inggris secara mandiri. 
2. Selain mendengarkan podcast, sebagian besar mahasiswa juga mendengarkan musik dan menonton film berbahasa Inggris sehingga mereka menjadi terbiasa untuk menyimak dalam bahasa Inggris sehari-hari.

3. Beberapa orang mahasiswa masih mengalami kesulitan dalam memahami topik yang didiskusikan dalam podcast. Untuk mengatasi hal ini, pada saat belajar bahasa Inggris mereka diperbolehkan untuk melihat transkrip percakapan.

4. Tingkat kesadaran mahasiswa mengenai pentingnya menguasai bahasa Inggris semakin meningkat. Mereka menyadari bahwa dengan menguasai bahasa Inggris, mereka akan jauh lebih mudah memperoleh informasi atau material, dalam bahasa Inggris, yang terkait dengan disiplin ilmu mereka. Mereka juga menyadari pada dasarnya bahwa mahir dalam bahasa Inggris akan memberikan nilai lebih bagi mereka pada masa yang akan datang.

Berdasarkan hasil dari penelitian yang telah dilakukan, maka dapat disimpulkan bahwa:

1. Podcast merupakan salah satu media belajar yang efektif untuk belajar bahasa Inggris.

2. Podcast dapat digunakan dengan mudah oleh setiap mahasiswa untuk belajar bahasa Inggris secara mandiri.

3. Para tenaga pendidik perlu meningkatkan penggunaan podcast dimana topik atau konten didasarkan pada tingkat kemampuan mahasiswa dalam memahami materi podcast berbahasa Inggris

4. Beragamnya konten podcast yang tersedia secara daring sangat memungkinkan mahasiswa untuk mendapat informasi tambahan yang dapat mendukung pemahaman mereka terhadap materi yang berkaitan dengan disiplin ilmu mereka.

\section{KESIMPULAN}

Penelitian ini telah mengungkapkan bahwa sebagian besar mahasiswa perguruan tinggi yang ada dikota Palangkaraya telah mengenal dan terbiasa menggunakan podcast sebagai salah satu media belajar mereka. Podcast juga menjadi media yang digunakan oleh para pengajar dikelas. Hal yang menjadi kelemahan para mahasiswa terkait dengan penggunaan podcast adalah masih ada beberapa mahasiswa yang memiliki keterbatasan dalam memahami bahasa Inggris. Hal ini menyebabkan mahasiswa tersebut memiliki kendala dalam memahami materi podcast yang menggunakan bahasa Inggris.

Dimasa mendatang, diperlukan penelitian lebih lanjut mengenai dampak penggunaan media belajar mandiri, seperti podcast, terhadap hasil belajar mahasiswa. Hal ini diperlukan untuk mengetahui sejauh mana keefektifan penggunaan metode belajar tersebut.

\section{DAFTAR PUSTAKA}

Abdulrahman, T., Basalama, N., \& Widodo, M. R. (2018). The Impact Of Podcasts On EFL Students' Listening Comprehension. International Journal of Language Education,2(2), 23. doi: 10.26858/ijole.v2i2.5878

Chan, A., \& Lee, M. J. W. (2006). An mp3 a day keeps the worries away: Exploring the use of podcasting to address preconceptions and alleviate pre-class anxiety amongst undergraduates information technology students. In the 2005 Student Experience Conference, Wagga Wagga, NSW, Australia. Retrieved from http://www.csu.edu.au/division/studserv/sec/papers/chan.pdf

Edirisingha, P. (2006). The 'double life' of an iPod - A case study of the educational potential of new technologies. University of Leicester, United Kingdom. Retrieved January 02, 2007, 
Fadilah, E., Yudhapramesti, P., \& Aristi, N. (2017). Podcast sebagai Alternatif Distribusi Konten Audio. Jurnal Kajian Jurnalisme, 1(1), 90-104. doi: 10.24198/jkj.v1i1.10562

Hargis, J. A. C. E., Schofield, Kathleen., \& Wilson, David. (2008). Fishing For Learning With A Podcast Net .i-Manager's Journal of Educational Technology,4(4), 34-38. Retrieved from http://www.unf.edu/dept/cirt/tech/podcast/ HargisPodcastArticle.pdf

Haris Budiman. (2017) Peran Teknologi Informasi Dan Komunikasi Dalam Pendidikan. Al-Tadzkiyyah: Jurnal Pendidikan Islam, Volume 8 No. I 2017, P.ISSN: 20869118, E-ISSN: 2528-2476. http://ejournal.radenintan.ac.id/index.php/tadzkiyyah/issue/view/221

http://www2.le.ac.uk/departments/beyonddistance-research-alliance/OnlineEduca2006/ OnlineEduca2006Presentations/OnlineEducaEdirisinghaPodcastPaper/view

Panday, P. P. (2009). Simplifying Podcasting. International Journal of Teaching and Learning in Higher Education, 20(2), 251-261. Retrieved from http://www.isetl.org/ijtlhe/

Riyani, R., \& Sari, A.I. (2020). Penggunaan Podcast untuk Memperbaiki Pengucapan (Pronunciation) Mahasiswa dalam Berbicara Bahasa Inggris. Research Fair Unisri, 4 (1), 1-15. Retrieved from http://ejurnal.unisri.ac.id/index.php/rsfu/article/view/3380 